\title{
Cattle management plan. Experience with communal lands holder
}

\section{Plan de manejo ganadero. Una experiencia con communal lands holder}

\author{
SOLIS-CAMPOS, Alicia $\dagger^{*}$ \\ Instituto Politécnico Nacional, CIIDIR-Durango, Mexico.
}

ID $1^{\text {st }}$ Author: Alicia, Solis-Campos / ORC ID: 0000-0002-6573-4633, Researcher ID Thomson: F-6544-2019, arXiv Author ID: AliciaSolis, CVU CONACYT ID: 374179

DOI: $10.35429 / J S R .2021 .19 .7 .1 .7$

Received January 10, 2021; Accepted June 30, 2021

\begin{abstract}
A systematization of a workshop course that took place in 2018 in the ejido of Nuevo Ideal, Durango, with the aim of agreeing actions to start a management plan, is presented. The workshop derived from work done to provide producers with tools and techniques that are useful for livestock exploitation, in addition to raising awareness of the need for actions for the protection and conservation of the natural resources offered to them by summer pasture ecosystems. The workshop was designed with five themes: Our Ejido, Livestock Management Plan, Grazing System, Infrastructure and Agreements. It is important to note that the agreement between PRONATURA northwest and the ejido for the implementation of a program that will help in the grazing system was the product of the workshop. The document is divided into three parts: Ejido, Design and implementation of the workshop, and Conclusions.
\end{abstract}

Course-workshop, Rural environment, Communal lands holder

\section{Resumen}

Se presenta la sistematización de un curso taller que se llevó a cabo en el año 2018 en el ejido de Nuevo Ideal, Durango, con el objetivo de acordar acciones para iniciar un plan de manejo en su ejido. El taller se deriva de un trabajo realizado para ofrecer a los productores herramientas y técnicas que son útiles para la explotación ganadera, además de concientizar sobre la necesidad de acciones para la protección y conservación de los recursos naturales que les ofrecen los ecosistemas del agostadero. El taller se diseñó con cinco temas: Nuestro Ejido, Plan de Manejo Ganadero, Sistema de Pastoreo, Infraestructura y Acuerdos. Es importante destacar la toma de acuerdos entre PRONATURA del noroeste y el ejido para la implementación de un programa que ayudara en el sistema de pastoreo fue el producto del taller. El documento se divide en tres partes: Ejido, Diseño e implementación del taller y, Conclusiones.

Curso-taller, Medio rural, Communal lands holder

Citation: SOLIS-CAMPOS, Alicia. Cattle management plan. Experience with communal lands holder. Journal of Social Researches. 2021. 7-19:1-7.

\footnotetext{
* Correspondence to Author (Email: asolisc @ipn.mx)

$\dagger$ Researcher contributing as first author.
} 


\section{Introduction}

The territory of the United Mexican States, better known as Mexico, is divided between 32 federal entities, of which Durango is one of them, being the fourth largest state in the Mexican Republic, it is subdivided into 32 municipalities, thanks to its extension and variety of climates and orography, the State allows its division into four regions: semi-desert, valleys, mountains, and ravines (Jiménez and Medina, 2011).

Nuevo Ideal is located in the region of the valleys, adjacent to three municipalities: Santiago Papasquiaro, which is located from the north to the west; Coneto de Comonfort, from the north to the east and Canatlán from the east to the south.

Durango has 1,118 ejidos and communities registered with the Ministry of Agrarian, Territorial and Urban Development (SEDATU, 2019), of which 29 belong to the municipality of Nuevo Ideal, where there is an ejido with the same name, and it was where it was carried out. the work experience that is systematized in this article.

Ranchers were offered a workshop with the objective of agreeing on actions to initiate a livestock management plan in their ejido. This workshop was important because it was part of a larger project where the objective was to offer the producers of the ejido of Nuevo Ideal, Durango, the tools and techniques useful for livestock exploitation, seeking above all to raise awareness of the need to apply protection and conservation of the natural resources offered by the ecosystems of the rangeland and with the workshop all the previous work was completed.

For this, several phases were carried out, from the collection of maps in the area, visits to the farm, to identify livestock, critical grazing points, impact on their development or recovery, in addition to sampling in the rainy season and comparing the grassland growth and development.

It is worth mentioning that this work was financed by PRONATURA northwest.
The document is divided into three parts: Ejido, which explains what an ejido is, its legal characteristics and the place where the work was carried out is dimensioned; Design and implementation of the workshop, where the structure and development of the workshop and the last part of Conclusions are explained, where the findings, agreements and what was observed during the workshop process, which was not part of it, are discussed.

\section{Ejido}

To contextualize the ejido, it is important to mention that it deals with agrarianism and communal lands, which are important not only for Mexico but for the entire world, since even the United Nations Food and Agriculture Organization, known as FAO for its acronym in English, commented since 2007 that although its conferences had decreased since 1979, "agrarian reform continues to be an important instrument for providing land to poor people in some countries" (Id. Ibid., p. .2) issuing guidelines for grazing reserve, agricultural exploitation and gender issues in land titles.

In Mexico, in accordance with article 27 of the Political Constitution of the United Mexican States (CPEUM) (1917), the bases for the acquisition and use of lands and seas are established, in addition to recognizing the forms of ejido and community.

For this, it is considered that an ejido is "a society of social interest, made up of Mexican peasants by birth, with an initial social patrimony made up of the lands, forests and waters that the State gives them free of charge as property" (Ruiz, 1990, p. 245), who is part of the ejido is known as ejidatario, and the communities are defined as the "population nucleus with legal personality and holder of agrarian rights (...) over their lands, pastures, forests and waters (...), which function according to the principles of internal democracy, cooperation and self-management according to their traditions and customs "(Id. Ibid., p.236), who make up the communities is known as comunero. 
According to the Agrarian Law [LA] (1992), the ejidos, in addition to having legal personality and their own patrimonies, the communal lands holder are owners of their lands, they must operate with internal regulations and register them in the National Agrarian Registry, there they must establish "The requirements to admit new communal lands holder, the rules for the use of common use lands, as well as (...) the others that each ejido considers pertinent" (Article 10)

Each ejidatario must make a list of heirs and register it before the National Agrarian Registry or before a notary public or notary public, in case of not doing so, his rights would be registered with the following order of preference: "to the spouse; to the concubine or concubine; one of the sons of the ejidatario; to one of his ancestors; and to any other person who is financially dependent on him "(L.A., 1992, article 18).

The organs of the ejidos considered in the Agrarian Law (1992) are:

Assembly. Considered as the supreme body and where all the communal lands holder participate, decisions are made there for the benefit of the communal lands' holder.

- Commissariat ejidal. He is the one who executes the agreements of the assembly, and they are made up of a president, a secretary and a Treasurer with their respective alternates. They are elected in assembly, with a duration of three years.

Supervisory Council. It is also made up of a president and two secretaries with their alternates, elected in assembly and for a duration of three years.

Ejido lands are divided into those that are destined for human settlement, those of common use and parceled lands (Id. Ibid.). The Nuevo Ideal ejido has 439 landowners, all of whom have the right of common use, but only 41 communal lands holder exercise that right. Of the $100 \%$ of the ejido surface, only $48 \%$ is suitable for cattle grazing, taking as a reference slopes less than $30 \%$, considering that on higher slopes the cattle do not gain weight and lose energy in search of their food.
The ejido is located in the municipality with the same name, with an elevation that ranges between 2,073 and 2,879 meters above sea level; It has a grazing area of 1000 hectares, where approximately 600 animals are fed, of which 400 individuals are adults with a weight per individual between 600 and $800 \mathrm{~kg}$. Some producers have equine cattle, and they do not have or apply a pasture management plan, they only take the animals in the month of May and lower them in December; for its management in the pastures of land for crops feeding on waste, stubble or some grasses that remain after sowing.

The Ejido Nuevo Ideal has several climates semi-dry temperate, temperate subhumid with rains in summer and semi-cold subhumid with rains in summer. The rainfall regime has its maximum precipitation of 100 to $180 \mathrm{~mm}$ in the months of June to September, while the period with low rainfall that is usually less than $20 \mathrm{~mm}$ occurs between the months of November to May.

The main species of vegetation identified are grasses (grasses), ferns, cacti, organs, biznagas, nopales, agaves, maguey sotol, huizaches, thorny bushes, manzanillos, oaks, tepozanes, táscate, mint and strawberry trees agave lechuguilla that is elusive, but it has little forage utilization. During the differentiation of the pastures in the pasture, the species of grass were detected: bermuda, pángola, barbón, foxtail, black grass, blue grass, medium fastuca, pink, navajilla and roder.

The hydrological zones are in very remote places in relation to the grazing sites of the animals, so they have to travel very long distances to meet their water needs, causing damage in hot season with subsequent consequences of dehydration and / or death in those with little physical resistance. In this way the animals generate a stay near the water holes, impacting on the soil structure, causing a phenomenon called compaction, which affects the retention, permeability and filtration of water.

\section{Workshop design and implementation}

The workshop was designed with the objective of agreeing on actions to initiate a livestock management plan for the Nuevo Ideal ejido, to which the following structure was established: 
Framing. To get to know the communal lands holder, their assistance interests and make decisions on how to carry out the workshop.

Our Ejido. With the aim of making the communal lands holder aware of what their ejido is, the characteristics of the livestock they have and the species of pasture they have.

Livestock management plan. To inform the communal lands holder of the livestock management plan and help them to make agreements.

- Grazing system. Where the communal lands holder is made aware of the proposed grazing system.

Infrastructure. They are made aware of the infrastructure required for the implementation of the grazing system within the livestock management plan.

Agreements. The communal lands holder is assisted to establish agreements to carry out the livestock management plan.

After preparing the descriptive letter corresponding to the course, its approval was requested, and it was implemented with the communal lands' holder.

The workshop was attended by 22 communal lands holder, of which 19 had livestock (the information on whether the attendees were all communal lands holder who had livestock, or if some were missing is unknown). This allowed the organization of 3 permanent teams according to how they felt comfortable with the other members,

At the beginning of the workshop, during the Framing, the communal lands holder were asked to introduce themselves and mention the reason (s) for which they were summoned or were there, in addition to reaching agreements that during the workshop the opinion of the residents would be respected. In addition, all those present committed themselves to participate in the activities and it was decided that instead of having long breaks, each one could get up during the work session to enjoy coffee or simply to stretch their legs.
After announcing the objective of the workshop, in the first topic Our ejido, an extract of the Agrarian Law was worked on as a team: team 1 read articles 9, 10 and 11 that deal with the internal regulations and provisions for exploitation collective of the ejidal lands, mentioning that the decisions are resolved through the assembly. Team 2 read articles 21 , 22 and 41, which establish the organs of the ejidos, emphasizing the functions of the commissariat, with respect to the registry book and the integration and operation of community councils, which should be established in their regulation. In team 3 , articles 43,44 and 45 of the law were reviewed, where the types of land in the ejido are established, in addition to mentioning that these can be the object of an exploitation contract, as long as it is carried out by the ejidal population and no older than 30 years. In plenary, all the teams established that they are an ejido, making it clear that, although they have their differences, it is important to discuss it among themselves.

For the second issue of Nuestro Ejido, the characteristics of the cattle were reviewed, showing images of six types of cattle: Aberdanangus, Angus, Beer master, Brangus, Cebu Brahmán and Charoláis, where they are asked to identify how much cattle they have among those who make up the team, resulting in that most have Charoláis, and they added the Criollos that did not come in any image presented, (See table 1).

\begin{tabular}{|c|c|c|c|c|}
\hline \multirow[t]{2}{*}{ Cattle breed } & \multicolumn{3}{|c|}{ Number of livestock per team } & \multirow[t]{2}{*}{ Totals } \\
\hline & Team 1 & Team 2 & Team 3 & \\
\hline Calf & 1 & 15 & 43 & 59 \\
\hline Aberdenangus & 2 & 0 & 24 & 26 \\
\hline Angus & 35 & 0 & 0 & 35 \\
\hline Beef master & 4 & 1 & 30 & 35 \\
\hline Brangus & 0 & 20 & 0 & 20 \\
\hline Zebu Brahman & 9 & 0 & 0 & 9 \\
\hline Patent leather & 88 & 3 & 480 & 139 \\
\hline Criollos & 0 & 64 & 29 & 93 \\
\hline
\end{tabular}

Table 1 Number of cattle by teams and race.

Source: Own creation with information from the workshop

They were also asked to write what the average weight is for each breed, so it was observed that the Brangus is the heaviest and there is a wide variation between the Criollos and the Beef master, (see table 2). 


\begin{tabular}{|c|c|c|c|c|}
\hline \multirow[t]{2}{*}{ Cattle breed } & \multicolumn{3}{|c|}{$\begin{array}{l}\text { Approximate weight } \\
\text { per breed in } \mathrm{Kg}\end{array}$} & \multirow[t]{2}{*}{$\begin{array}{c}\text { Average } \\
\text { weight }\end{array}$} \\
\hline & $\begin{array}{c}\text { Team } \\
1\end{array}$ & $\begin{array}{c}\text { Team } \\
2\end{array}$ & $\begin{array}{c}\text { Team } \\
\mathbf{3}\end{array}$ & \\
\hline Calf & 350 & & 180 & 265 \\
\hline Aberdenangus & 350 & & 400 & 375 \\
\hline Angus & 350 & & & 350 \\
\hline Beef master & 350 & 600 & 400 & 450 \\
\hline Brangus & & 756 & & 756 \\
\hline $\begin{array}{l}\text { Zebu } \\
\text { Brahman }\end{array}$ & 350 & & & 350 \\
\hline Patent leather & & 400 & 450 & 400 \\
\hline Criollos & 0 & 640 & 350 & 495 \\
\hline
\end{tabular}

Table 2 Average weight of cattle by breed in $\mathrm{kg}$.

Source: Own creation with information from the workshop

In the third activity of our ejido, the communal lands holders were asked to identify the type of pasture that their lands have, showing images of those that were registered, but between team 1 and team 3 they only identified 5 hectares of pink grass. and 5 hectares of Navajita grass, also when they were asked to write if they knew of another grass that was not among the images, these two teams identified in the parceled hectares:

\section{- Zacate Johnson: 13.5 hectares.}

\section{- $\quad$ Zacate Grama: 43 hectares.}

\section{- $\quad$ Chinese grass: 28 hectares.}

Regarding the lands considered as common use, team 1 and team 2 indicated the following:

- $\quad$ There are 1000 hectares of grass grass.

There are 2,600 hectares distributed in three types of grass: foxtail, grass and Chinese, with 6.7 hectares remaining per ejidatario ${ }^{1}$.

In covering the pasture, 3 questions were reflected on: What benefits do I obtain from cattle? What do I need to get better results? Is the grass eaten by the cattle in my ejido enough?

They were asked to reflect on the questions for themselves so that the answers could be written, but when they read the third question in unison, they answered that the grass eaten by cattle in their ejido was not enough.

\footnotetext{
${ }^{1}$ The members of team 2 divide 2,600 hectares between 388 communal lands holder

Afterwards, five more questions were presented, which they worked as a team presenting their answers in Table 3.

\begin{tabular}{|c|c|c|c|}
\hline Question & Team 1 & Team 2 & Team 3 \\
\hline $\begin{array}{l}\text { How much } \\
\text { grass does a } \\
\text { cow require to } \\
\text { feed itself } \\
\text { properly? }\end{array}$ & $\begin{array}{l}\text { One } \\
\text { hectare } \\
\text { per cow } \\
\text { on flat } \\
\text { land and } \\
10 \\
\text { hectares } \\
\text { on hilly } \\
\text { land per } \\
\text { cow }\end{array}$ & $\begin{array}{l}10 \% \text { of your } \\
\text { weight, if } \\
\text { you weigh } \\
400 \mathrm{~kg} \text { you } \\
\text { require }\end{array}$ & $\begin{array}{l}20 \mathrm{~kg} \text { in } \\
\text { daily } \\
\text { green }\end{array}$ \\
\hline $\begin{array}{l}\text { Is the amount of } \\
\text { grass on my } \\
\text { property } \\
\text { enough? }\end{array}$ & No & No & No \\
\hline $\begin{array}{l}\text { If we add the } \\
\text { cows that are } \\
\text { owned and the } \\
\text { grass that is } \\
\text { compared, is it } \\
\text { enough for the } \\
\text { total number of } \\
\text { cows? }\end{array}$ & No & No & No \\
\hline $\begin{array}{l}\text { If a cow dies of } \\
\text { hunger, whose } \\
\text { problem is the } \\
\text { owner or the } \\
\text { ejido? }\end{array}$ & $\begin{array}{l}\text { From the } \\
\text { owner of } \\
\text { the cattle }\end{array}$ & $\begin{array}{l}\text { From the } \\
\text { owner of the } \\
\text { cattle }\end{array}$ & $\begin{array}{l}\text { Of the } \\
\text { owner }\end{array}$ \\
\hline $\begin{array}{l}\text { If there are } \\
\text { feeding } \\
\text { problems with } \\
\text { cattle, when is it } \\
\text { the ejido's } \\
\text { problem and } \\
\text { when is it the } \\
\text { owner's } \\
\text { problem? }\end{array}$ & $\begin{array}{l}\text { It is the } \\
\text { problem } \\
\text { of the } \\
\text { ejido } \\
\text { when } \\
\text { there is } \\
\text { no } \\
\text { support } \\
\text { and of } \\
\text { the } \\
\text { owner } \\
\text { when he } \\
\text { does not } \\
\text { give } \\
\text { adequate } \\
\text { attention } \\
\text { to the } \\
\text { cattle. }\end{array}$ & $\begin{array}{l}\text { It is a } \\
\text { problem for } \\
\text { the ejido } \\
\text { when there } \\
\text { is over- } \\
\text { exploitation } \\
\text { of common } \\
\text { use land. } \\
\text { Food is the } \\
\text { owner's } \\
\text { problema }\end{array}$ & $\begin{array}{l}\text { Personal } \\
\text { problem }\end{array}$ \\
\hline
\end{tabular}

Table 3 Question and answers by teams regarding the diagnosis of grassland cover

Source: Own creation with information from the workshop

At the end of these activities, the decision is made in plenary to join the issues of grazing systems with the livestock management plan, where the issues are explained to the communal lands holders and it is proposed that they can feed their livestock with hydroponic forage during the dry season. 
The Infrastructure explains that it would require the construction of a space, where it is suggested that at least 200 cows get together to graze during the months of June and July, so that the opportunity is provided for the grazing areas in the part middle and upper part of the ejido are recovered, and to delimit at least a first pasture.

It is worth mentioning that the representative of PRONATURA northwest offered the institution financial support for its construction. At the end of the workshop, the communal lands holders discussed the boundaries and identified the delimited area, suggesting that an assembly meeting be scheduled to make the proposal, since the construction was proposed in a common area, an assembly was necessary for the decision final, and they were organized with 2 communal lands holders who would present the proposal in the assembly.

\section{Acknowledgments}

PRONATURA northwest is thanked for its financing and without which this process with the farmers would not have been concluded.

\section{Conclusions}

At the end of the workshop, the objective of reaching an agreement was achieved, especially that they were aware that the way in which they are grazing their cattle is not working as they expected, despite the fact that it was desirable that the Decisions were made at the end of the workshop, this was not possible, due to the regulations that prevail in the ejidos.

It is important to mention that, of those attending the workshop, a third did not know how to read or write, one of them had hearing problems, so he took his son to do or help him with the activities, another was the first one time he attended an ejido meeting, and another one attended with walking problems.

Despite these difficulties and the fact that the room where the workshop was located did not have the necessary acoustics for good listening, its ceiling was made of sheet metal and it was raining very hard, the communal lands holders showed solidarity and support for the attendees, they read to them, they They helped to understand legal concepts, among other actions that made the workshop run successfully.
Regarding the breed of cattle, it was found in the workshop that the largest amount is between Charolais and Criollas, of which, according to their own report, they have an approximate weight of 400 and $495 \mathrm{~kg}$ per head, which is not coincides with what was reported by the veterinarian who reports that "400 specimens are adults with a weight per individual between 600 and $800 \mathrm{~kg}$ " that is because, if the 59 reported calves are counted, they add up to 416 animals and the average does not reach $600 \mathrm{~kg}$.

It was also observed that a team mentions that there are 1000 hectares, which coincides with the first report received, but one team mentions 2,600 hectares, mentioning that this is in common use, but when making the division, the team performs it between 388 communal lands holder instead of 439 that was initially reported, which implies a lack of knowledge in the total of the holder communal lands and the total of hectares that are of common use or parceled out.

The communal lands holders were aware of the need for a livestock management plan, that they need to agree to graze the cows, so that everyone benefits, which means changing routines and sharing delimited areas among their livestock.

It was interesting to note that some ranchers were hesitant to accept financial support and spend it where recommended (on an electric fence), but they agreed that the decision had to be made in the assembly, so it was not possible to decide at that time.

\section{References}

Constitución Política de los Estados Unidos Mexicanos [CPEUM], 1, Diario Oficial de la Federación, Estados Unidos Mexicanos, pp. 1321, (5 de febrero de 1917) [Last reform on May 8, 2020]. Recovered from: http://www.diputados.gob.mx/LeyesBiblio/pdf_ mov/Constitucion_Politica.pdf

Jiménez F., M., y Medina R., H. (2011). Durango. La entidad donde vivo. [Tercera edición, 2014]. México: Secretaría de Educación Pública. 
Ley Agraria [L.A.], 1, Diario Oficial de la Federación, Congreso de la Unión, pp. 1-55, (26 de febrero de 1992), [Last reform published on June 25, 2018] Recovered from: http://www.ordenjuridico.gob.mx/leyes.php

Ruiz M., M. (1990). Derecho Agrario. México: Universidad Nacional Autónoma de México.

Secretaría de Desarrollo Agrario, Territorial y Urbano (SEDATU). Registro Agrario Nacional. Catálogo de núcleos agrarios de la propiedad social. Consulted in: https://datos.gob.mx/busca/dataset/catalogo-denucleos-agrarios-de-la-propiedad-social

Organización de las Naciones Unidas para la Agricultura y la Alimentación [FAO] (noviembre, 2007) Conferencia Internacional sobre Reforma Agraria y Desarrollo Rural (CIRADR): resultados y seguimiento. (K0938S). Publicado en Conferencia de la FAO $34^{\circ}$ Periodo de sesiones. (C2007/INF/21) From 17 to 24 November 2007 in Rome. Recovered from:

http://www.fao.org/tempref/docrep/fao/meeting /012/k0938s.pdf 